\title{
Optimization Strategy of Laku Pandai Policy in Islamic Bank: A Case Study
}

\author{
Junarti1 ${ }^{1}$, Saiful Anwar², Fitra Anisa ${ }^{3}$
}

\begin{abstract}
Laku Pandai is a program providing banking services and/or other financial services through cooperating with other parties (bank agents) and supported by the usage of modern facilities to increase and expand any accesses to financial services. Laku Pandai is quite effective and efficient if its implementation and optimization are conducted by the banks that are eager in expanding their services in lower average cost. As for how it is, its significant development then triggered BRI Sharia to participate. However, Financial Services Authority thinks that conventional banking is not yet optimal, so it comes up with an argumentative assumption on Islamic banking if it successfully implements the program. The purpose of this study is to determine appropriate strategies for optimizing Laku Pandai outputs in Islamic banking using SWOT and AHP analysis. SWOT analysis is used to determine internal and external factors related to application of the output, while AHP is used to capture the best precise strategy. The result of the research shows that the main output of Laku Pandai is to successfully reach unbanked people with the exact alternative that is by improving marketing and promotion, improving socialization and education to society, improving agent quality and establishing vision and mission.
\end{abstract}

Keywords: Laku Pandai, SWOT, AHP

Abstrak. Laku Pandai merupakan program penyediaan layanan perbankan dan/atau layanan keuangan lainnya melalui kerjasama dengan pihak lain (agen bank) dan didukung dengan penggunaan sarana teknologi informasi untuk meningkatkan dan memperluas akses layanan keuangan. Laku Pandai cukup efektif dan efisien jika diterapkan dan dioptimalisasikan oleh perbankan yang ingin berekspansi dengan biaya rendah. Perkembangan Laku Pandai yang cukup signifikan akhirnya memicu BRI Syariah untuk turut serta. Namun menurut penilaian Otoritas Jasa Keuangan, Laku Pandai perbankan konvensional belum optimal. Sehingga muncul argumentasi mungkinkah perbankan syariah berhasil menerapkan program tersebut. Tujuan penelitian ini untuk menentukan strategi-strategi yang tepat dalam mengoptimalisasikan produk Laku Pandai di perbankan syariah dengan menggunakan analisis SWOT dan AHP. Analisis SWOT untuk menentukan faktor internal dan faktor eksternal terkait penerapan produk tersebut sedangkan AHP untuk menentukan prioritas strategi yang tepat. Hasil penelitian menunjukkan bahwa sarasan utama produk Laku Pandai adalah menjangkau unbanked people dengan strategi alternatif yang tepat, yaitu meningkatkan marketing dan promosi, meningkatkan sosialiasi dan edukasi kepada masyarakat, meningkatkan kualitas agen dan menetapkan visi dan misi.

Kata Kunci: Laku Pandai, SWOT, AHP

\footnotetext{
${ }^{1}$ STIE Ahmad Dahlan Jakarta| junarti92@gmail.com

${ }^{2}$ STIE Ahmad Dahlan Jakarta | olieanwar@gmail.com (corresponding author)

${ }^{3}$ Universitas Indonesia | fitraanisa393@gmail.com
} 


\section{Introduction}

Islamic banking has great potential to develop and expand in wide ranges in Indonesia, in accordance with the fact claiming that Indonesia is the largest moslem-majority country in the world. Ironically, the development of Islamic banking market share is under development. Moneter.com (2016) argued that approximately 24 years, it finally reached $5.13 \%$ (at the end of 2016) due to the conversion of BPD Aceh with the increase of Islamic banking assets (BUS and UUS) of 18.49\% (yoy); IDR 272.6 trillion (July 2015) to IDR 305.5 trillion (July 2016). In addition to the lack of government support, the challenges faced by Islamic banking today are the restricted access of products and services to other banking services.

This obstacle becomes the current challenges of Islamic banking that, thus, it requires the Islamic banking aware of any problems appear. In other words, there must be certain ways which are not on the contrary to the principle Islamic sharia.

Laku Pandai (branchless banking) and sharia financial services have potential to be well synergized, referring to the conceptual commonality that is inclusive finance aiming at providing easy, cheap, safe, and appropriate financial access for the community, and to increase societies' capability. On the other hands, the principles of Islamic banking aim at building societies' prosperity through partnership and profit sharing.

In other countries Laku Pandai program is known as branchless banking. Based on Ignacio (2012), branchless banking entails a convergence of services from banks, telecoms, and retail players. This presents the challenge of determining what kinds of partnerships and business models will be most conducive to accelerating this convergence.

One of branchless banking which succeeded and got a lot of attention is M-Pesa in Kenya. The success of Safaricom's M-PESA, a mobile money service in Kenya, has inspired many practitioners, but the true test lies in the ability of other markets to translate M-PESA's success into their own context 
and create an environment that promotes expansive and sustainable retail financial services (Ignacio, 2012).

Table 1. Progress of Laku Pandai in Indonesia

\begin{tabular}{|c|c|c|c|c|c|}
\hline & June 2015 & $\begin{array}{c}\text { September } \\
2015\end{array}$ & $\begin{array}{c}\text { December } \\
2015\end{array}$ & March 2016 & June 2016 \\
\hline $\begin{array}{l}\text { Number of } \\
\text { Banks } \\
\text { Providing }\end{array}$ & $\begin{array}{l}6 \text { Banks } \\
\text { (Bank } \\
\text { Mandiri, } \\
\text { BRI, BNI, } \\
\text { BTN, BTPN, } \\
\text { and BCA) }\end{array}$ & 6 Banks & $\begin{array}{l}7 \text { Banks } \\
\text { (+ BPD } \\
\text { Kaltim) }\end{array}$ & $\begin{array}{c}9 \\
\text { Commercial } \\
\text { Banks } \\
\text { (+ Bank } \\
\text { Sinarmas } \\
\text { and } \\
\text { Bukopin) }\end{array}$ & $\begin{array}{c}\text { 13 Commercial } \\
\text { Banks, } \\
\text { there are } 12 \\
\text { conventional } \\
\text { banks (Bank } \\
\text { Sahabat } \\
\text { Sampoerna, BJB } \\
\text { and Bank } \\
\text { Jateng) and } 1 \\
\text { Islamic Bank } \\
\text { (+ BRI Sharia) }\end{array}$ \\
\hline $\begin{array}{l}\text { Number of } \\
\text { individual } \\
\text { agents / legal } \\
\text { outlets }\end{array}$ & $\begin{array}{c}3,734 \\
\text { Agents }\end{array}$ & $\begin{array}{l}19,411 \\
\text { Agents }\end{array}$ & $\begin{array}{l}60,805 \\
\text { Agents }\end{array}$ & $\begin{array}{l}84,374 \\
\text { Agents }\end{array}$ & 104,707 Agents \\
\hline $\begin{array}{l}\text { Total } \\
\text { outstanding } \\
\text { accounts }\end{array}$ & $\begin{array}{c}35,984 \\
\text { Customers }\end{array}$ & $\begin{array}{l}\text { 1,061,076 } \\
\text { Customers }\end{array}$ & $\begin{array}{c}1,216,952 \\
\text { Customers }\end{array}$ & $\begin{array}{l}\text { 1,351,798 } \\
\text { Customers }\end{array}$ & $\begin{array}{l}\text { 1,626,068 } \\
\text { Customers }\end{array}$ \\
\hline $\begin{array}{l}\text { Total } \\
\text { outstanding } \\
\text { savings }\end{array}$ & $\begin{array}{l}\text { IDR } 2.9 \\
\text { Billion }\end{array}$ & $\begin{array}{l}\text { IDR } 40 \\
\text { Billion }\end{array}$ & $\begin{array}{l}\text { IDR } 67 \\
\text { Billion }\end{array}$ & $\begin{array}{l}\text { IDR } 50 \\
\text { Billion }\end{array}$ & IDR 63 Billion \\
\hline $\begin{array}{l}\text { Number of } \\
\text { provinces } \\
\text { where the } \\
\text { agent }\end{array}$ & $\begin{array}{c}30 \\
\text { Provinces }\end{array}$ & $\begin{array}{c}33 \\
\text { Provinces }\end{array}$ & $\begin{array}{c}34 \\
\text { Provinces }\end{array}$ & 34 Provinces & 34 Provinces \\
\hline $\begin{array}{l}\text { Number of } \\
\text { districts / } \\
\text { cities }\end{array}$ & $\begin{array}{l}211 \text { (of total } \\
514 \text { districts } \\
\text { / cities) }\end{array}$ & $\begin{array}{c}368 \text { (of total } \\
514 \text { districts } \\
\text { / cities) }\end{array}$ & $\begin{array}{c}385 \text { (of total } \\
514 \text { districts } \\
\text { / cities) }\end{array}$ & $\begin{array}{c}\text { 427(of total } \\
514 \text { districts } \\
\text { / cities) }\end{array}$ & $\begin{array}{l}499 \text { (of total } 514 \\
\text { districts / cities) }\end{array}$ \\
\hline
\end{tabular}

The progress of Laku Pandai (table. 1) is increasingly significant that impacts on the increasing number of parties involved in encouraging the growth of Islamic banking in Indonesia, especially in certain areas where sharia banks are foreign i.e. new institutions so owned by the shareholders but also belongs that the prosperity expands more evenly and eventually will 
increase the asset of Islamic banking. But unfortunately, only BRI Sharia has been implementing Laku Pandai program in June 2016. The asset on banking is crucial and urgent in case of its expansion and competition to other banks. This also aims at giving profitable benefit toward all kinds of ranges of societies surrounding. In another word, the bank is not only as an institution to the surrounding community. Therefore, the banks should pay attention and any strategies to increase its asset. The existence of Laku Pandai program should be an alternative in proving to the societies, where they live in rural areas, concerning on Islamic banking that is unequal to conventional banking through the existence of Laku Pandai. Yet, the applied Laku Pandai program by conventional banking is still considered less than optimal.

Based on the survey applied by the Financial Services Authority published on Kompas Oct 5th, 2016 states, "Laku Pandai is not optimal. The success of Laku Pandai is not measured by the number of unofficial or branchless banking agents. In this case, the number of the societies who get accessed on the existence of Laku Pandai program may become its evidence. The fact may show the increasing of a bill or bank account". The statement of the Financial Services Authority confirms that the current program i.e. Laku Pandai is not optimal yet, as the existing of unofficial or branchless banking agents and increasing in each period is not proportional to the increase in the outstanding savings.

Relating to the statements on the previous passage, a question comes up. How does Islamic banking optimize Laku Pandai program with low average asset and unwell-known or unfamiliar system among societies, in different from conventional banking? To overcome this issue, Islamic banking must apply the own circled strategy in utilizing Laku Pandai program. The use of a precise strategy which is seen best influence its competition to the conventional banking which has applied from this program since earlier. Moreover, the term of sharia is unfamiliar with the societies. 


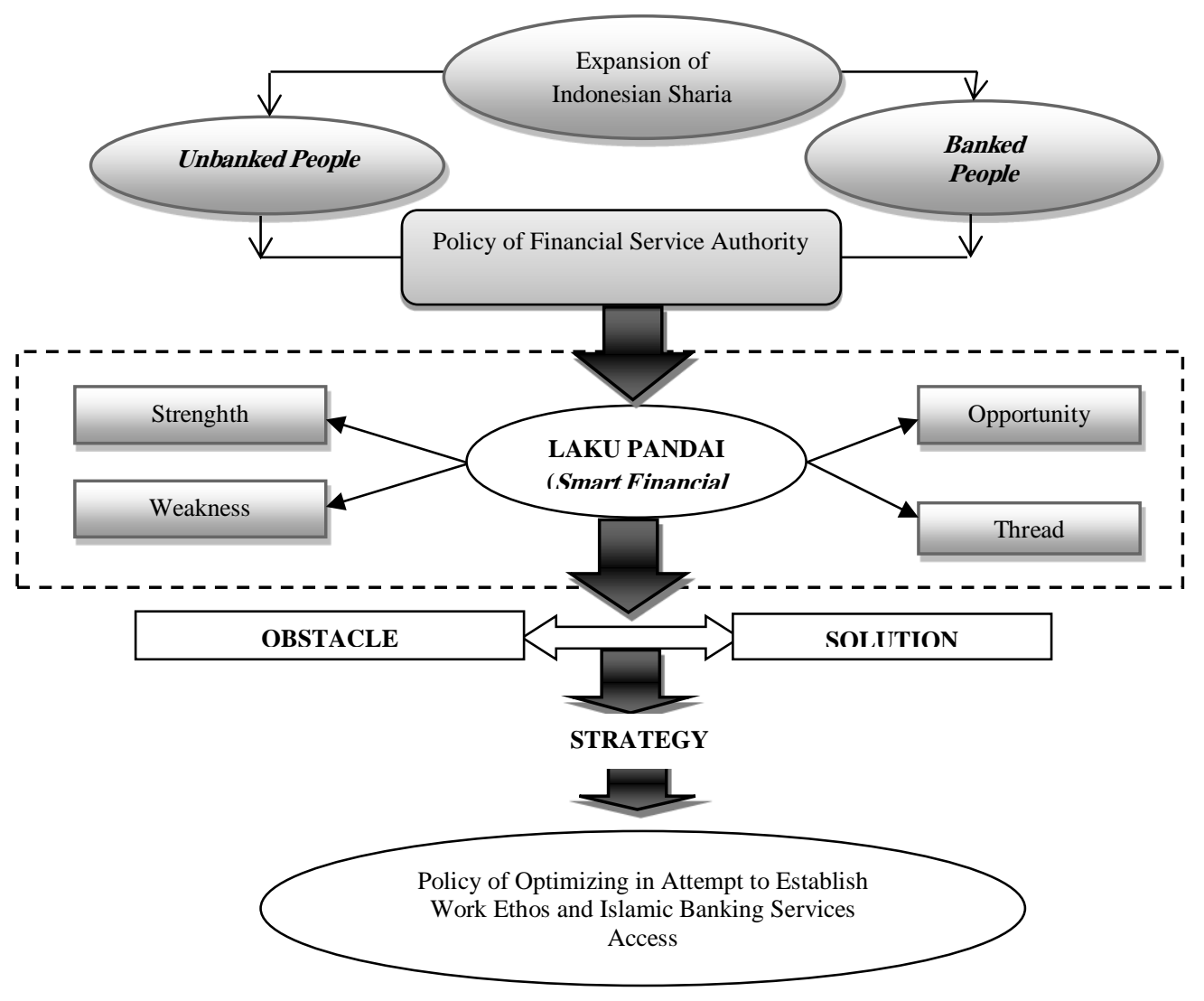

Figure 1. Mind Mapping

\section{Literature Review}

Theoretically, Al-Qur'an does not declare banking term implicitly rather than mentioning a case that has elements such as structure, management, function, right and duty. It is mentioned clearly as tithe, alms, booty (ghanimah), sale and purchase (bay'), debt (dayn), treasures (māl) and so on, which have functions performed by certain roles in economic sectors. Islamic banks in general are financial institutions whose main orientation is providing credit and services and other payments, as well as the circulation of money operated in accordance with the principles of sharia (Arif, 2012).

Based on No.19/POJK.03/2014, According to the Financial Services Authority, "Laku Pandai is abbreviated from Non-Office Financial Services in the Framework of Inclusive Finance, which is a program of providing banking 
services and / or other financial services through cooperating with other parties (bank agents) and supported by the use of modern facilities."

Smart Programs published by the Financial Services Authority are based on the following matters: (a) Large number quantities of the societies who do not yet know, use, or get accessed on banking or financial services. This condition may be due to limited access on the banking office and, or burdened taxes or costs; (b) The Financial Services Authority, the banking industry, and other financial services industries are committed to support the realization of inclusive finance; (c) The Government of Indonesia launched the National Inclusive Financial Strategy (SNKI) program on June 2012, one of which is branchless banking program and; (d) Existing branchless banking needs to be developed to enable banking services and other financial services that reach all levels of society throughout Indonesia.

The objectives to be achieved by this policy are: (a) Provide simple, easyto-understand financial products that meet the needs of people who have not been able to reach current financial services and; (b) With the increasing number of members of various community groups in various regions in Indonesia using financial services/banking, it is expected that the economic activities of the community can be more smoothly so as to encourage economic growth and equitable development among regions in Indonesia, especially between villages.

According to Indonesian Dictionary (1994), optimization is derived from the word optimal which means best, highest, most profitable, best possible, make the highest, optimize the process, the way, the act of optimizing (make best, highest, and etc.) so that optimization is an action, process, or methodology for making something (as a design, system, or decision) to be more/fully perfect, functional, or effective.

\section{Method}


According to Sugiyono (2012), research method is basically a scientific way to get data with a specific purpose and usefulness. Based on this theory, there are four key words to note: the scientific way, data, purpose, and usability.

The method used in this research is the case study method (observational case studies) with a quantitative approach that combines the input of qualitative and quantitative data as well (mix method). Further, the authors moved from case studies that produce qualitative data input (human perception) with the help of questionnaires.

This research is descriptive because this research intends to collect various data and information that exists then describes and analyzes facts in the field. The selection of approaches in this study will be begun by outlining the strengths, weaknesses, opportunities and challenges in the application of Laku Pandai then analyzing it to form a strategy.

In qualitative research, a sample of the data sources was chosen purposively and was snowball sampling. On the early stage of getting sampling is having engaged with selected people who have power and authority in social situations or objects studied, so as to "open the door" where and how the researchers will perform data collection (Sugiono, 2012).

Based on the criteria related to selected samples, the researcher chooses three samples as data sources that will represent the ranges of the research stages that are the practitioner of BRI Sharia bank covering head of division of related research, funding officer and agent of Laku Pandai, the academician from the institute of education of STIE Ahmad Dahlan Jakarta.

The steps of data tabulation of qualitative research according to Irawan (2006) are as follow: First, data collection obtained through interviews, field observation and literature review. Second, the data collection obtained through interviews in form of transcripts and fieldnotes are changed into written form of report. Third, coding transcription, rereading all transcribed data and retrieving keywords. Forth, data categorization, simplifying data by binding 
key concepts (words) in magnitudes. Fifth, remarks of concluding, i.e. temporary decision making. Sixth, triangulation, having check and recheck between one source with other data sources. And the last final conclusion, i.e. the final process of the whole steps. The final conclusion is taken when the data are saturated and each addition of new data only means redundant.

The first step in this research is to find as much as information about the application of Laku Pandai in Islamic banking then is followed by data mapping through SWOT approach in the form of internal and external factor analysis. This approach is an IFAS-EFAS matrix obtaining some of the most appropriate/ dominant strategic alternatives according to the scale of priority. Of the several alternative strategies are then made selection of need priority scale, including issues raised in each level using the AHP model. The results of the model will be recommended as an alternative optimization strategy in decision making to achieve the expected goals.

\section{SWOT}

The concept of modern strategy that is oriented towards Strenghths, Weaknesses, Opportunities, and Threats (SWOT) that produce the driving factors, inhibitors and potential. Each component of the SWOT constraint is defined as follows: Strenghths are resources or organizational capacities that can be used effectively to achieve goals; Weaknesses are limitations, tolerances, or organizational defects that hinder the achievement of goals; Opportunities are a supportive situation within an organization that is illustrated by similar trends or changes or views needed to increase the demand for products/ services and enable the organization to improve its position through supply activities; Threats are situations which do not support (obstacles, constraints or other external elements) in an organization environment that potentially undermines the strategy that has been set, so that they cause problems, damage or errors. 


\section{AHP (Analytic Hierarchy Process)}

The AHP method was developed by Thomas L. Saaty, the mathematician. This method is a framework for making effective decisions on complex issues by simplifying and accelerating the decision-making process by solving the problem into its parts, arranging parts or variables in a hierarchical order, assigning numerical values to subjective considerations of the importance of each variable and synthesizes these considerations to determine which variables having the highest priority and acting to influence outcomes in those situations.

\section{Result and Discussion}

\section{SWOT Analysis}

SWOT analysis is the first step for this research in the framework of choosing alternatives in optimizing the Laku Pandai program of Islamic banking.

Table 2. Assessment of Weight Internal Factors Analysis System (IFAS)

\begin{tabular}{|c|c|c|}
\hline No. & Strenghths & Rating \\
\hline 1 & Islamic values unite with the small community; & 0.20 \\
\hline 2 & $\begin{array}{l}\text { Laku Pandai is one of the services of Islamic banking products that is } \\
\text { more equitable and make people prosperous; }\end{array}$ & 0.22 \\
\hline 3 & $\begin{array}{l}\text { Service existing on the Laku Pandai is in accordance with the needs of the } \\
\text { community; }\end{array}$ & 0.22 \\
\hline 4 & $\begin{array}{l}\text { The existence of sharia supervisory board that ensures the products of } \\
\text { Islamic banking to its consistency; bias of deviation; }\end{array}$ & 0.31 \\
\hline 5 & Laku Pandai is a solution for the expansion of Islamic banking at low cost; & 0.33 \\
\hline 6 & Potentially to survive in conditions of economic crisis; & 0.15 \\
\hline 7 & $\begin{array}{l}\text { Under the auspices of the government and the financial services } \\
\text { authorities in accordance with legislation; }\end{array}$ & 0.23 \\
\hline No. & Weaknesses & Rating \\
\hline 8 & The vision and mission of the Laku Pandai program is not yet clear; & 0.31 \\
\hline 9 & Lack of agents' competent of the Laku Pandai ; & 0.20 \\
\hline 11 & Business models referring to conventional banking; & 0.24 \\
\hline 12 & The information system of Islamic banking is still low; & 0.20 \\
\hline 13 & Lack of marketing and promotion; & 0.33 \\
\hline 14 & Lack of socialization and education to the community; & 0.33 \\
\hline 15 & Islamic banks have not been serious in the development of Laku Pandai. & 0.20 \\
\hline
\end{tabular}


Based on the weighting results of SWOT elements as seen (table 2 and 3), the power factor having the highest rating value is the Laku Pandai that it is the solution for the expansion of Islamic banking with low cost. The lowest rating value in the weakness factor is the lack of marketing and promotion and lack of socialization and education to the community. The highest rating value in the opportunity factor is majority of the population of Indonesia is moslem and most of the small areas have a stronger Islamic knowledge. The lowest rating value in the opportunity factor is the community who has not been technologically-minded and the wider network of branchless conventional banking bank.

Table 3. Weight Assessment of External Factors Analysis System (EFAS)

\begin{tabular}{clc}
\hline No. & \multicolumn{1}{c}{ Opportunities } & Rating \\
\hline 1 & The majority of Indonesians are moslem; & 0.30 \\
2 & Most of small areas have stronger Islamic knowledge; & 0.30 \\
3 & Moslem scholars are close to the communities; & 0.23 \\
4 & The customer is not exclusively devoted to moslems; & 0.26 \\
5 & Expanding the network to all corners of the country; & 0.28 \\
6 & Ease of any accesses of Islamic banking customers; & 0.28 \\
8 & The increase of funds on the third party and market share; & 0.21 \\
9 & Long-term profit; & 0.23 \\
\hline No. & & Thating \\
\hline 10 & Most of the communities are contaminated with conventional banks; & 0.26 \\
11 & Lack of moslem communities' understanding of the usury; & 0.21 \\
12 & Features of Islamic banking services are generally strange; & 0.20 \\
13 & Society is not technologically minded yet; & 0.30 \\
14 & Conventional branchless banking networks of conventional banks & 0.30 \\
& are wider; & The increase of reputation risk. \\
\hline
\end{tabular}

Source: Respondent's Assessment the Researchers

To know the priority and the linkage between strategies based on SWOT weighting, interaction of internal-external strategy combination is done. The 
formulation of these strategies is based on internal strengths and weaknesses and external factors and threats into IFAS - EFAS SWOT matrix form. In summary, the results of the IFAS-EFAS matrix formulation based on SO, ST, WO, and WT strategies are evaluated to determine their scale of priority. An alternate arrangement based on the priority sequence obtained from SWOT interaction synthesis is presented in the following table (table 4 and 5)

Table 4. The Weighting SWOT

\begin{tabular}{c|cc}
\hline & $\mathbf{S}=\mathbf{1 . 6 5 2}$ & $\mathbf{W}=\mathbf{1 . 8 1 2}$ \\
\hline $\mathbf{O}=\mathbf{2 . 1 0 1}$ & $\mathrm{SO}=3.753$ & $\mathrm{WO}=3.913$ \\
$\mathbf{T}=\mathbf{1 . 5 4 0}$ & $\mathrm{ST}=3.192$ & $\mathrm{WT}=3.353$ \\
\hline \multicolumn{3}{|c}{ Source: Result of Data Organizing }
\end{tabular}

From the result of weighting the questionnaire (table 4), then the priority of strategy is set based on the combination of strategies that have the highest value to the lowest.

Table 5. Alternative Sequencing of SWOT Strategy

\begin{tabular}{clc}
\hline Priority & \multicolumn{1}{c}{ Strategy } & Weight of Value \\
\hline I & Weakness-Opportunity (WO) & 3.913 \\
II & Strength - Opportunity (SO) & 3.753 \\
III & Weakness-Threat (WT) & 3.353 \\
IV & Strength - Threat (ST) & 3.192 \\
\hline \multicolumn{3}{c}{ Source: IFAS - EFAS Interaction Matrix }
\end{tabular}

The IFAS-EFAS interaction result (table. 5) generates the most weighted alternative strategy is the Weakness-Opportunity (WO) that can be translated as strategies minimizing weaknesses by taking advantage of existing opportunities. This condition is quite worrisome sharia banks especially BRI Sharia, because the internal factors of BRI Sharia has a weakness that is greater than the strength. But from the external side, the opportunities greater than the threats in order to optimize the program of Laku Pandai.

\section{AHP Policy Strategy Formulation}


To set the hierarchy is the most important part in determining the AHP model because it will be the basis for the respondents to give a simple assessment/opinion. Witb

GOAL e simpler so

this study consists of 4 levels, with the top level as the geal / focus of the $1 \begin{gathered}\text { Level 1 } \\ \text { Scenario }\end{gathered}$ the "Q Optimist trate Status Quo and Pessimist Sharia Banking". At the strategy levincluded as an atternative peliey strategy is the chosen strategy based on SWOT analysis restfthat is WQ

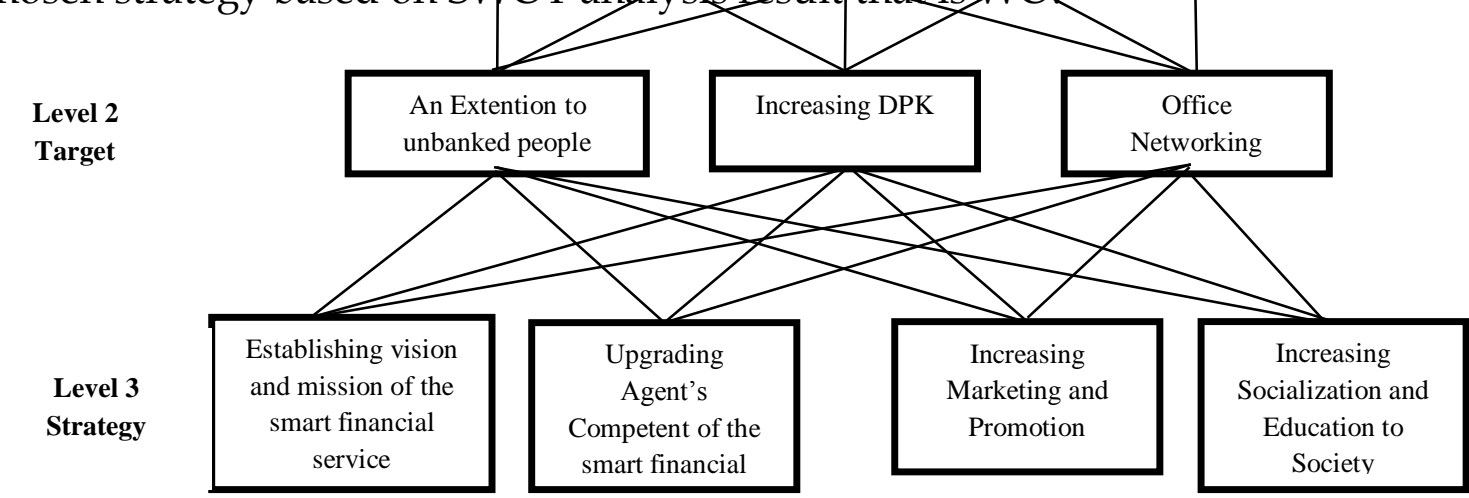

Figure 2. The Hierarchy of AHP Model

Based on the given weighting, then the data organizing is performed by pairwise comparison method. The result concluded that the strategy of optimizing the Laku Pandai of Islamic banking in Indonesia, the scenario that is considered important, is optimistic on the prioritized target that is to afford unbanked people. To achieve these targets, the orders of policy priorities that can be done by Islamic banking are as follows: 
Table 6. The Sequence of Optimization Strategy on the Policy of Laku Pandai on Islamic Banking

\begin{tabular}{clc}
\hline Priority & \multicolumn{1}{c}{ Policy Strategy } & Weight \\
\hline I & Expanding Marketing and Promotion & 0.353 \\
II & Increasing socialization and education to society & 0.282 \\
III & Upgrading the agent's competent & 0.239 \\
IV & Establishing vision and mission & 0.125 \\
\hline & \multicolumn{1}{c}{ Total Weight } & $\mathbf{1 . 0 0 0}$ \\
\hline
\end{tabular}

The main objective to be undertaken by BRI Sharia based on respondents' assessment is to reach unbanked people.

Unbanked people in Madura area of East Java are not only people who live in remote areas such as Mandangin Island, but also people living in the city belonging to lower middle class but they have obstacles - constraints to save in the bank, such as: (1) People who work day-to-day in the market or work as a school teacher so they do not have time to come to the bank to save. (2) People shrink to come to the bank because of their mindset that banks are only for the upper middle class. (3) The community with low average incomes that it causes them hard to save.

These obstacles are opportunities to develop Laku Pandai using the method of picking up the ball. The BRI Sharia Bank Agent comes to a community that is considered potential to save, such as markets, schools and housewives.

Based on the data organizing using AHP to achieve these targets, the priority of optimization strategy of Laku Pandai as follows:

Increasing Marketing and Promotion (Priority I)

Marketing and promotion are the strategy that exists in the business. Kotler and Armstrong in the book of Marketing Management, a linguist Teguh (2002) states that through marketing and promotion following objectives can be achieved: (1) Insisting the consumer's awareness. If most of the target audience is unaware of the object, the purpose of the promotion is to build awareness in form of the introduction of the product. (2) Providing 
the consumer's information. The target audiences may already have an awareness of the company or product but do not know much more. So the promotional part of the promotion contains a lot of information about the product. (3) Creating consumer preferences. If the target audience knows the product, the question now is whether the consumer likes it or not. So that the communicator must find the reason and then develop a communication campaign to encourage feelings of liking. (4) Improving and maintaining consumer preferences. Preferences in the sense of preferring to certain products rather than to other products. (5) Convincing consumers. Consumers may prefer a particular product but do not generate the conviction to buy it. The task of promoting is to ensure that the products offered truly provide solutions for consumers. (6) Encouraging consumers to buy. Many target audiences may have confidence but do not intend to make a purchase. They may wait for more information or plan to act later. Communicators should lead consumers to take the final step. The trick can be to offer products at low prices, offer, premium, or provide limited opportunities to customers to try.

As the program of the Laku Pandai ages 2 years old, it is fair that a few people question about what it is.

\section{Increasing Socialization and Education to The Society (Priority II)}

Majority of the population of Indonesia is moslems, but the market share is only $5 \%$. It is most likely caused by ignorance of moslems about Islamic banking and its proscription on the interest so that the strategy of education and socialization becomes the solution. Socialization and education itself is not entirely assigned to sharia banks, but can also work with academics, moslem scholars and community leaders. The cooperation is an effort to develop and socialize economy, finance and Islamic banking.

\section{Upgrading Agent's Competent (Priority III)}

Improving agent competent is an important strategy. The agent is the extension of sharia banks to the public. If the quality is good of course 
customers will not hesitate to choose Islamic banks. Some things that can be done to improve the quality of agents, based on survey results, are: (1) Education and training. This activity is important in order to increase the insight of the Laku Pandai agents on the banking sector and other financial services as well as on the principles of sharia in transactions. In addition, it will establish a good relationship between agents and internal human resources of Islamic banking. (2) Rewards / incentives. Rewards / incentives are surpluses which are bestowed for agents. It is important to trigger the performance of agents in finding customers as well as introducing Islamic banking products both inside and outside the Laku Pandai (which are available under sharia banks). (3) Availability of facilities and infrastructure. Islamic banks should provide facilities and infrastructure for agents to make them easier to serve customers such as providing printers (photocopies), ballpoints, paper and other tools. In this case, the agent is one of the spearheads of the Laku Pandai program. Therefore, to maintain the loyalty of agents it requires the role of sharia banks in order to not over-handing to other banks.

\section{Setting Vision and Mission (Priority IV)}

Setting vision and mission of the Laku Pandai program is a strategy that aims at determining the objectives and steps taken to achieve goals of the Laku Pandai. Because this program has a good prospect in the future and potentially becomes long-term product, but up to now the Laku Pandai sharia bank still referring to conventional bank, sharia banks should have a uniqueness either from its ways of covenant or agreement, profit sharing, its usefulness, and friendship with the community and so forth, namely by incorporating elements of Islam in its operation. In addition to a clear vision and mission, Laku Pandai can be one product to combat conventional banks through the middle to lower society.

\section{Conclusion}


Based on SWOT and AHP result, the strategic issues faced by Islamic banking in optimizing the Laku Pandai program are as follow: First, improving and expanding marketing and promotion to the entire community; Second, improving education and socialization to the community about the presence of Islamic banking in accordance with Islamic principles and free of any kinds of usuries; Third, improving the quality of Laku Pandai agents through training in Islamic banking, rewards for the best agents; Forth, establishing the vision and mission of the Laku Pandai in order to be more directed. Islamic banks have potential to expand and stand in the remote areas, as most of the inhabitants of remote areas of Indonesia still have strong beliefs and are more confident in transactions with sharia methods. However, this potential is not maximized by sharia banks because the funds collected from the public are considered small and require a long time. Therefore, Islamic banking only focuses on products that earn more funds.

The results of this study are not an absolute strategy that must be done by Islamic banking in optimizing the Laku Pandai program of sharia banks. Due to the many deficiencies that lay on the process of data collection and organizing as in review of literature, so it is suggested to further research to: (1) Determine more than one research object in order to compare the conditions and needs of society; (2) Increase the number of respondents of the research of Islamic banking experts so that the quality of research is better. If it is crucial, the role of Financial Services Authorities may be involved.

\section{References}

Al Arif, M. N. R. (2012). Lembaga Keuangan Syariah Suatu Kajian Teoritis Praktis. Pustaka Setia. Bandung.

Anggraeni, N. (2015). Pengaruh Layanan 3 in 1 Maslahah (Branchless Banking) terhadap Pertumbuhan Dana Pihak Ketiga (DPK) dan Efisiensi Biaya Operasional Bank pada PT. Bank BJB Syariah. Doctoral dissertation, Fakultas Syariah UNISBA.

Ascarya and Yumanita, D. (2010). Determinan dan Persistensi Margin Perbankan Konvensional dan Syariah di Indonesia. Working paper series 
No.WP/10/04. Pusat Pendidikan dan Studi Kebanksentralan Bank Indonesia.

Ascarya. (2011). The Persistence of Low Profit and Loss Sharing Financing in Islamic Banking: The Case of Indonesia. Review of Indonesian Economic and Business Studies, Vol. 1.

Asri, D.A. (2010). Strategi Kebijakan Pembangunan Daerah Kabupaten Klaten: Pendekatan Analisis SWOT dan AHP. Tesis UI Program Magister Perencanaan dan Kebijakan Publik. Jakarta.

Bank Indonesia. (2015). Laporan Perekonomian Indonesia 2015 "Bersinergi Mengawal stabilitas, Mewujudkan Reformasi Struktural. ISSN 0522-2572.

Departemen Penelitian dan Pengaturan Perbankan. (2015). Seputar Informasi Mengenai Layanan Keuangan Tanpa Kantor dalam Rangka Keuangan Inklusif. Otoritas Jasa Keuangan.

Heene, A and Sebastian D. (2015). Manajemen Strategik Keorganisasian Publik. Cetakan Kedua. PT Refika Aditama, Bandung.

Heri, S. (2015). Bank dan Lembaga Keuangan Syariah Deskripsi dan Ilustrasi. Edisi Ke 4 cet ke-3. Ekonisia, Yogyakarta.

Hubeis, M. and M. Najib. (2014). Manajemen Strategik dalam Pengembangan Daya Saing Organisasi. PT Elex Media Komputindo Kompas Gramedia, Jakarta.

Ignacio, M. (2012). Branchless and Mobile Banking Solutions for the Poor: A Survey of the Literature. Innovations, Vol. 6(4).

Jeni, W. (2009). Strategi Pengembangan Kawasan Industri Kecil Berbasis Komoditas Unggulan (Studi Kasus Kawasan Sentra Industri Keripik Kota Bandar Lampung). Tesis, Univesitas Indonesia. Jakarta.

Junarti, and Saiful, A. (2016). Faktor-Faktor yang Mempengaruhi Peningkatan Dana Pihak Ketiga Perbankan Syariah (Studi Kasus pada Bank Umum Syariah Periode 2010-2014). Konferensi Islamic-EBD 2016.

Karim, A. (2012). Bank Islam Analisis Fiqih dan Keuangan. Edisi Kempat. PT Raja Grasindo Persada, Jakarta.

Otoritas Jasa Keuangan. (2015). Seputar Informasi Mengenai Layanan Keuangan Tanpa Kantor dalam Rangka Keuangan Inklusif (LAKU PANDAI). Departemen Penelitian dan Pengaturan Perbankan.

Otoritas Jasa Keuangan. Penjelasan atas POJK Nomor 19/POJK.03/2014 tentang Layanan Keuangan Tanpa Kantor Dalam Rangka Keuangan Inklusif, hal 1.

Philip, K. (2002). Manajemen Pemasaran Edisi Millenium 1. Translated by Hendra Teguh and Ronny A. Rusli. PT. Prenhalindo, Jakarta.

Prasetya, I. (2004). Metode Penelitian. Universitas Terbuka, Jakarta. 
Prasetya, I. (2006). Penelitian Kualitatif and Kuantitatif Untuk Ilmu-Ilmu Sosial. Departemen Ilmu Adminstrasi FISIP UI, Jakarta.

Pungki, P. (2013). Branchless Banking Setelah Multilicense: Ancaman Atau Kesempatan Bagi Perbankan Nasional. Delivered in order to comply one of Bank Indonesia Leadership Staff School Requirements (SESPIBI).

Saaty, T.L. and Vargas L.G. (2006). Decision Making with the Analytic Network Process Economic, Political, Social and Technological Applications with Benefits, Opportunities, Cost and Risk. Springer International Series.

Saiful, A. and Kenji, W. (2011). Performance Comparison of Multiple Linear Regression and Artificial Neural Networks in Predicting Depositor Return of Islamic Bank. 2010 International Conference on E-business, Management and Economics.

Saiful, A. and Rifki, I. (2011). Robustness Analysis of Artificial Neural Networks and Support Vector Machine in Making Prediction. Parallel and Distributed Processing with Applications (ISPA). IEEE 9th International Symposium on IEEE.

Saiful, A. and Yoshiki M. (2011). Comparing Accuracy Performance of ANN, MLR, and GARCH Model in Predicting Time Deposit Return of Islamic Bank. International Journal of Trade, Economics and Finance, Vol. 2 (1): 4451.

Sugiyono. (2012). Metode Penelitian Kuntitatif, Kualitatif dan RED. Alfabeta, Bandung

Tanjung, $\mathrm{H}$ and Devi, A. (2013). Metodologi Penelitian Ekonomi Islam. Gramatika Publishing, Bekasi.

Wibowo, P. W. (2013). Branchless Banking Setelah Multilicense: Ancaman atau Kesempatan Bagi Perbankan Nasional. Bank Indonesia, Jakarta. 